Paper for the POLIS 2005 PLENARY CONFERENCE

Paris: Sciences Po, 17-18 June 2005

"European Identity and Political Systems"

WORKSHOP 6:

NEW POLITICAL IDENTITIES: SOCIAL MOVEMENTS, MIGRANTS, AND MINORITIES IN

EUROPE

\title{
Title: A minority at the border: EU enlargement and the Ukrainian minority in Poland
}

Abstract

This paper examines the effects of EU enlargement on the position of the Ukrainian minority in Poland. The enlargement has set two conflicting developments into motion that both may have a serious influence on national minorities in countries at the peripheral borders of the enlarged EU. On the one hand, there is a development towards increased protection of the external borders (see, the incorporation of the Schengen system into the EU). At the same time, however, a new move has become perceptible within the EU towards increased political, security, economic and cultural cooperation with the new neighbouring countries in the east (made concrete, e.g., in the European Neighbourhood Policy). This paper explores what these two opposite trends mean for the Ukrainian minority in Poland. More in particular, have Ukrainian minority actors in Poland actively seized the EU enlargement as a new political opportunity for making their claims heard in domestic politics, stimulating processes of reconciliation, and preventing further ethnic polarisation? Or have they perceived the enlargement of the EU as an obstacle hindering the process of reconciliation between ethnic groups and as a factor further complicating historical disagreements between Poles and Ukrainians?

\section{Author}

Peter Vermeersch

Department of Political Science

Institute for International and European Policy

University of Leuven (KU Leuven)

E. Van Evenstraat 2B, B-3000 Leuven, Belgium

Peter.Vermeersch@soc.kuleuven.ac.be

This is a draft paper. Please do not quote or distribute. Comments are welcome. 


\section{Introduction}

National minorities in countries at the peripheral borders of the enlarged European Union (EU) find themselves in an intriguing new situation. This is especially the case for minorities that now have a neighbouring non-EU country as their "external national homeland" (Brubaker 1996). The EU enlargement has set two conflicting developments into motion that might have a profound impact upon the position of these minorities. On the one hand, there is the hardening of the external borders of the EU (through, e.g., the incorporation of the Schengen system into the EU, the development of a European border agency, etc.). This development is likely to render cross-border contacts between minority populations at the borders of the EU and their ethnic kin in neighbouring non-EU countries more difficult. It may weaken the position of minority groups; it may also galvanise group feeling among minorities and majorities, stimulate thinking in ethnic collectives, and hamper discussions between minorities and majorities about how to resolve historical disagreements.

On the other hand, however, a new move has become perceptible within the EU towards increased political, security, economic and cultural cooperation with the new neighbouring countries in the east (made concrete most clearly in the Commission's European Neighbourhood Policy). This latter trend is explicitly meant to prevent the emergence of dividing lines between EU-members and their neighbouring countries. It may therefore, in theory at least, encourage initiatives for cross-border co-operation, cut across the traditional nationalist narratives in which ethnic actors typically frame their demands, and create a context that facilitates reconciliation between ethnic minorities and majorities.

The question is: How is EU enlargement most likely to be understood by minority groups: merely as just another phase in a complicated history of conflict, or as a real opportunity to raise a political voice, promote interests, and lobby for change? This paper examines this question for a specific ethnic minority group living in a historically embattled cross-border region at the external border of the current enlarged EU. The small Ukrainian national minority in Poland - which according to last Polish census (2002) numbers 31.000 people, i.e. less than $0.1 \%$ of the total Polish population (Główny Urząd Statistyczny 2003) ${ }^{1}$ - is an instructive case precisely because Polish-

\footnotetext{
${ }^{1}$ In 2000, Ukrainian minority activists estimated the number of Ukrainians in Poland to be somewhere between 200,000 and 300,000. In response to the much lower figure in the 2002 census, activist groups such as e.g. the Association of Ukrainians in Poland (Zwiazek Ukrainców $w$ Polsce) issued press releases in which they claimed that irregularities during the census had created a bias in the official numbers. As is true in other cases, census figures suggest a level of clarity and stability which is not there (see, Kertzer and Arel 2002). Identity is dependent on context. In Poland, some people may be regarded as Ukrainians but may not identify themselves as such, while others who think of themselves as Ukrainians might not (always) use this identity in a public context. Moreover, since Ukrainians were dispersed over the Polish territory after World War II and were made subject to linguistic assimilation, there is a discussion as to whether language (the ability to speak Ukrainian or the tendency to use Ukrainian as a language of preference) should be considered as a necessary attribute of Ukrainian identity. Matters are further complicated by recent immigration from Ukraine and the high rate of intermarriages between Poles and Ukrainians (Górny and Kępińska 2004).
} 
Ukrainian relations have been marked by conflict as well as co-operation. The collapse of communism has, on the one side, highlighted the atmosphere of mutual recriminations between Poles and Ukrainians related to the historical episodes of violence and displacement during and after the Second World War. Yet, since the early 1990s there have also been important political forces in Poland who have actively pursued a strategic partnership with Ukraine. Although Polish-Ukrainian relations within Poland have been characterised by intense conflict over past injustices, on the elite level and in international politics Poland and Ukraine were able to establish good relations. This article asks how the accession of Poland to the EU has impacted upon this state of affairs.

The paper contains four sections. The first offers a brief outline of a conceptual and theoretical framework derived from literature on the role of "transnational political opportunity structures" in bringing about or preventing processes of ethnic cooperation and conflict. The second section discusses the most important political and institutional changes on the European level and shows that such changes may, in theory, have an impact on the position of the Ukrainian minority in Poland. The third section starts with a brief overview of the situation of the Ukrainian minority in Poland and the development of Ukrainian minority activism since 1989. Section four then goes on with an examination of the current position of Ukrainian minority activism in the central governmental institutions in Poland. This examination is partly based on a content analysis of the documents produced by these governmental bodies and the transcripts of the discussions held between 2001 and 2005 in the Polish lower house (Sejm).

I will conclude that while European integration has clearly been a dominant structuring force when it comes to international diplomatic relations between Poland and Ukraine and the regulation of cross-border contacts, so far it has had little impact on processes of reconciliation between Poles and Ukrainians in Poland. I close the paper by providing a number of possible explanations for the main finding that current Ukrainian minority activism in Poland has not been able to benefit much from the firm Polish support for Ukraine on the international level.

\section{Theoretical background: minority activism and political opportunities}

Why would one expect the position of the Ukrainian minority in Poland to have been influenced by the changing international environment? More in general, on what theoretical basis would one argue that ethnic relations in a domestic arena may be significantly affected by changes in international politics?

There are two broad fields of theoretical research that give rise to making such assumptions. The first is a body of sociological literature on the nature of minorities. Brubaker $(1996 ; 2004)$ is one of the authors who have argued convincingly that national minorities should not be seen as fixed entities, but rather as dynamic and relational political "fields." On this view, being a minority is not simply a matter of ethnic or national identity; it is the product of processes of identification and 
categorization in which political action plays an important role. Leaders, activists, and politicians use the language of national identity to mobilise people for specific identity projects and thereby "evoke" minorities and majorities. According to Brubaker, nationalism should be seen as the result of a relationship between three dynamic and contested political fields: national minorities, nationalizing states and external homelands. Seen in this way, ethnic relations are what results from the ongoing interaction between at least three groups of actors: minority activists, state actors and actors who are related to what is perceived as the external "homeland" of a minority population. In other words, the experience of what it is to belong to a minority is closely linked to the way political actors domestically and in an international context apply the language of national and ethnic identity. When important changes occur in the fields of the nationalizing state or the external homeland, it is likely that this will create changes within the field of the national minority.

The second relevant body of theoretical literature deals with social movements and globalization. Social movement research has argued that changes in the political and institutional contexts that surround a social movement will lead to changes in the way such a movement acts. In other words, this literature claims that movements including ethnic movements - will be affected by the political and institutional contexts (the "political opportunity structure" or POS) in which they operate. In order to seize opportunities, movement leaders will adjust their collective action strategies. These general contentions are at the heart of what have become known as "political opportunity" and "political process" theories (Kriesi, Duyvendak and Koopmans 1995; McAdam 1982; McAdam, McCarthy and Zald 1996). Social movements, these theories argue, are to a large extent shaped by their interaction with the political opportunity structure that surrounds them. ${ }^{2}$ Students of globalization, in turn, have argued that these political opportunities are not strictly related to the domestic arena. Social movements, an increasing number of authors argue, are clearly affected by global processes (such as the growing power of intergovernmental institutions and multinational corporations, and the increasingly global reach of the media). Activists have pushed their action beyond state borders and have in these global processes found new opportunities and resources for influencing both state and nonstate actors (Keck and Sikkink 1998). Once largely ignored by movement scholars, recent studies have built on the POS approach to argue that movement formation is in fact profoundly influenced by transnational political opportunities (see, e.g., Guidry, Kennedy and Zald 2000).

\footnotetext{
2 McAdam (1996), for example, has distinguished the following dimension of the POS: the access to the political system, the divisions within the ruling elite, the availability of elite allies, and the level of state repression. Seeking to develop a broad pallet of theoretical tools for the analysis of social movements McAdam and others have not restricted themselves to these structural factors. They have also identified mechanisms of influence related to political agency such as framing techniques (Benford and Snow 2000; McAdam, McCarthy and Zald 1996; Meyer 2004).
} 


\section{Empirical background: the potential influence of EU enlargement on Ukrainian political activism in Poland}

If the above theoretical contentions correctly identify the international context as a crucial factor shaping domestic ethnic politics, one should certainly expect this factor to be influential in the case of the Ukrainian minority in Poland. In fact, there are a number of characteristics of the relationship between Poles and Ukrainians in Poland that would lead one to presume that the international context in this case has been particularly important.

First of all, when Poland after 1989 sought to "return to Europe," the country exposed itself to Europe-wide political discourses on the importance of minority protection standards. In the beginning of the 1990s, international organizations in Europe gave increasing legitimacy to norms on minority protection and began monitoring minority protection in individual democratizing states such as Poland. One would expect minority activists in democratizing countries to have been able to rely on these norms to buttress their political action. Social movement scholars today increasingly argue that movements may more easily than in the past "amplify" their demands in the domestic arena by relying on the monitoring activities of international organizations (Risse and Sikkink 1999: 18). This has certainly been true in the field of ethnic relations in Europe. Since the beginning of the 1990s, transnational social movements promoting minority rights have managed to gain a certain amount of influence on the normative agenda of European international organizations. These international organisations, in turn, have increasingly become active participants in the shaping of legal developments and policies towards minorities in domestic arenas. This has been particularly clear in Central and Eastern Europe. The Organization for Security and Cooperation in Europe (OSCE), the Council of Europe, and the EU have all applied various techniques (from soft "normative pressure" to hard "membership conditionality") to pressure the countries in this region in order to change domestic state behaviour towards minorities and prevent ethnic conflict (Kelley 2004).

The influence of norms on minority protection gained even more power in the countries of Central Europe when EU membership ceased to be merely a dear wish and became a realistic prospect. Although traditionally not a part of the European integration agenda, the EU attached great importance to minorities in the context of its eastward enlargement. In the course of the 1990s, the EU member states gradually committed themselves to the principles of human rights protection and anti-discrimination, most notably through the Maastricht and Amsterdam Treaties. But the EU's concern for minority protection in the neighbouring countries in Central and Eastern Europe was clearly much more pronounced than its internal commitment. Already in the beginning of the decade the desire to contain or prevent ethnic conflict became part and parcel of the EU's external relations towards the candidate countries in Central Europe. This was, of course, to a great extent the result of the EU's earlier inability to prevent and respond to the acute outbreak of violence in the Balkans and its subsequent fear for the emergence of similar conflict scenarios in other former communist countries. The EU sharply accentuated the role of minority protection in the Copenhagen criteria for 
accession, hoping that by so doing it would be able to maintain political stability throughout the future territory of the Union, especially in areas were ethnic relations were volatile. It is reasonable to assume that this development also had its effect in areas where there never was an immediate danger for a large-scale international conflict involving minorities, such as, for example, the eastern border zones in Poland.

Furthermore, one would expect the situation of the Ukrainians in Poland not only to have been affected by the processes that led to Poland's accession to the EU, but also by the current policies of the enlarged EU towards the east. One policy development that is potentially important for Ukraine as well as for the Ukrainians in Poland is the European Neighbourhood Policy (ENP). The ENP should be seen in the context of the European Commission's initiatives since the early 2000s to create alternatives to further enlargement to the East. The ENP seeks to establish closer relations with the countries bordering the enlarged EU as an alternative to EU membership. In one of the key speeches leading up to the ENP, Romani Prodi made clear that the main driving force behind the new strategy was the need felt to put limits to the expansion of the EU:

'[W]e cannot go on enlarging forever. We cannot water down the European political project and turn the European Union into just a free trade area on a continental scale. We need a debate in Europe to decide where the limits of Europe lie and prevent these limits being determined by others. We also have to admit that currently we could not convince our citizens of the need to extent the EU's borders still further east' (Prodi 2002, emphasis in original).

In the further development of the ENP, however, the Commission tried to shift attention away from the issue of the limits of enlargement and began to put emphasis on the issue of co-operation with the new neighbours of the EU. In February 2005, the commissioner currently responsible for the ENP, Benita Ferrero-Waldner, wrote an article for a Ukrainian weekly in which she highlighted this shift of focus: 'let's be clear, this is a plan to bring Ukraine closer to Europe, not to hold it in any way at arm's length.' (Ferrero-Waldner 2005, emphasis in original).

In addition to the ENP there is also a move perceptible in the EU to stimulate crossborder regional development (see, e.g., local cross-border initiatives, such as the Bug and Carpathian Euroregions at the Polish-Ukrainian border). These initiatives, however, are either still rather vague (in case of the ENP) or lack sufficient financial support from the EU (in case of the formation of cross-border regions). Therefore it is not unlikely that these initiatives will be overshadowed by issues related to the hardening of the external border of the EU. These initiatives are obviously less useful for purposes of domestic minority activism.

While it might still be true that "EU borders' policies are in flux, caught between forging links across external borders and policing it" (O'Dowd and Wilson 1996: 13), it is, however, quite likely that border policing is becoming the EU's more important concern. First of all, a number of new initiatives in the field of justice and home affairs are to be found in the area of the increased protection of the external borders. Secondly, the 
incorporation of the Schengen aquis into the EU framework clearly had its effects on Polish-Ukrainian relations. Before becoming a member of the EU, Poland had to introduce a visa regime for Ukrainian citizens in accordance with the Schengen requirements (Vermeersch 2005). As a result, there was a marked decrease in the number of border crossings (Fidev 2004). Arguably, this not only had an effect on the economic level (see, e.g., the small-scale trade between Ukraine and Poland) but, on a more general level, also on the way in which in border areas the history of the relationship between Ukrainians and Poles will be perceived. As Wilson and O'Dowd have formulated it, borders are "reminders of the past". Any transformation of borders means engaging with the past (O'Dowd and Wilson 1996: 1).

It is obvious that international developments in general have a significant effect on diplomatic relations between Poland and Ukraine. This is reflected in the way international relations between the two countries evolved in the course of the 1990s. In keeping with the analysis made by Wolczuk and Wolczuk (2002), one may distinguish three periods from 1991 to 2004. In the first, between 1991 and 1994, Poland's foreign policy was driven by the country's will to improve its prospects of joining NATO. In this context, there was little time and effort devoted to improve economic and political cooperation with Ukraine, although Poland kept being supportive of Ukrainian independence. From 1994 onwards, after the presidential elections in Ukraine and Poland, Poland put its cooperation with Ukraine more and more at the heart of its eastern policy. What followed was a brief period during which both countries stepped up their political, economic and military cooperation efforts. Polish policy in this period was mainly driven by a concern to avoid a far-reaching Russian influence right at its eastern borders. After 1998, the relations deteriorated again, mainly as a result of Poland's preoccupation with joining the EU and the EU's apparent lack of interest in Ukraine.

In more recent times, Poland has again been able to improve relations by actively supporting Ukrainian's bid to become a candidate for EU membership and has lobbied for a flexible visa regime for Ukraine (Vermeersch 2005). Poland repeatedly took a proUkraine stance in its dealing with the EU. While, as a result of its accession negotiations with the EU, Poland was obliged to introduce a visa regime for Ukrainian citizens, ${ }^{3}$ it still managed to make Ukraine a priority in the ENP and stimulated the creation of a European action plan specifically directed towards Ukraine.

Poland could furthermore evidence its willingness to support Ukraine's "return to Europe" by playing a crucial role in the "orange revolution". When in November 2004 the Ukrainian election results sparked off widespread popular protest, Polish political leaders (such as President Kwaśniewski) and activists from the former Solidarność movement could successfully win the sympathy of the crowds of protesters in Kyiv. And even more importantly, they sat down at the negotiation table forging the deal that would lead to a repeat of the second round of the elections. Poland found itself in a

\footnotetext{
3 In 2004, the new visa regime caused huge waiting lines at the Polish consulates in Ukraine. The press reported complaints of corruption (See, Wilczak 2004).
} 
strong position as an ally of the Ukrainian popular movement for democracy and received simultaneously strong backing from the EU, which had been particularly sharp in its denunciation of the large-scale electoral fraud that had marred the first election results.

One aspect of this episode that was not discussed widely in international press reporting about the orange revolution was the wave of sympathy that protesters in Kyiv were able to create in Poland. Although some of it may have been guided by Polish popular nostalgia for a time of unity in opposition against undemocratic leaders and a common fear of new threats to democracy coming from Russia, it might nevertheless have contributed to a better atmosphere for dealing with past Ukrainian-Polish antagonisms.

It has been argued that Poland's EU membership has added another layer of complexity to Polish-Ukrainian relations because this had affected the "strategic relations" between Warsaw and Kyiv to a much greater extent than Poland's joining to NATO in 1999 (Wolczuk and Wolczuk 2002: 3). It is not unlikely that this complexity will be most clearly felt by Ukrainians in Poland. If there is indeed an international opportunity structure shaping Ukrainian activism in Poland, it should be to some extent visible in the way in which Ukrainian activism developed in recent years.

In sum, the Ukrainian minority appears to have gained an extra opportunity for political action as a result of the recent developments in the context of Poland's accession to the EU. The discursive dimension of European enlargement may, in other words, form an important factor changing the context of contemporary social memories in PolishUkrainian relations.

\section{Ukrainian minority activism in Poland: a brief overview}

Ukrainian minority activism in Poland cannot be understood without seeing it against the backdrop of the complex history of the area that now forms the eastern part of Poland. The current borderland region between Poland and Ukraine was for a long time a peripheral area that remained unaffected by central attempts at nation- and statebuilding. Chris Hann has used the term "polytacticity" to characterize the local political and social relations in this area at the end of the $19^{\text {th }}$ century. Hann defines polytacticity as the situation in which the "lumpy features that we nowadays refer to as 'ethnic groups' or 'cultures' did exist, but not as sharply bounded units asserting exclusive rights over territory. Identities cross-cut each other, and different ties and allegiances were activated in different contexts" (Hann 1998: 843). In the 20th century, however, the Ukrainian and the Polish nations gradually but forcefully became the dominant foci for identity in this region.

Some of the most crucial events in this history of national community formation were related to the First and the Second World Wars and their aftermaths. After the First World War, when Poland was again put on the map after more than a century of non- 
existence, claims for dominance in the regions of eastern Galicia and Volhynia caused tensions and fighting between Ukrainians and Poles. ${ }^{4}$ In the period between the wars, Poland introduced stringent assimilation policies towards the Ukrainian population in its eastern provinces, which, in turn, allowed the paramilitary forces of the Ukrainian national movement to build up their mobilizing potential in these regions. In the beginning of the 1930s, complaints were laid at the League of Nations, and Western states severely criticized the Polish authorities for oppressing about 3 million Ukrainians and by so doing creating receptive ground for Russian influence in the region. ${ }^{5}$ During the Second World War, a civil war between Poles and Ukrainians broke out during which the military wing of the Organization of Ukrainian nationalists (OUN), the Ukrainian Insurgent Army (UPA), engaged in violent ethnic cleansing campaigns directed against Polish communities. Large numbers of Poles were killed and, in return, a large number of Ukrainians died as victims of reprisals by the Polish resistance army (AK) (Czech 1993).

When in 1944 the borders of the new Polish state were established, the Polish National Liberation Committee (PKWN) agreed with the government of Soviet Ukraine to initiate a large-scale population exchange operation. According to some sources, 482.000 people were relocated from Poland to Ukraine in the period from September 1944 to June 1946 (Czech 1993: 268). In 1947, a large-scale forced resettlement operation was organized, replacing approximately 140,000 people identified as Ukrainians to the north and the west of Poland (Ackja Wisła or "Operation Vistula"). The basic idea underpinning these initiatives was to obliterate support for the UPA in the eastern regions. In practice, the primary objective soon turned out to be the assimilation of Ukrainians and the elimination of Ukrainian identity in the Polish eastern regions by dispersing Ukrainians among Poles in the rest of the country (see, e.g., Snyder 1999).

This history left a clear imprint on the way in which Ukrainian-Polish relations were experienced during the post-World War II period. What happened is that particular events (especially the events related to the civil war, the establishment of the border, and the resettlement campaigns) were becoming important elements in the formation of specific, distinctive national narratives among Poles and Ukrainians in which each portrayed the other nation as responsible for creating injustices and initiating violent conflict. Narrating and commemorating certain past events are important in the formation of what has been called 'mnemonic communities' (Irwin-Zarecka 1994, Zerubavel 1999). In an effort to construct, promote and preserve a feeling of national

4 The area comprised the interwar Polish wojewódstwa of Lwów, Stanislawów, Tarnopol, and Wolyn, which (with the exception of the far west of Lwów wojewódstwo) were incorporated into Soviet Ukraine in 1945, and which now constitute the Lviv, Ivano-Frankivsk, Ternopil', Volhynia, and Rivne provinces (oblasti) of independent Ukraine (Snyder 1999: 88).

${ }^{5}$ Sir Walter Napier's speech delivered in 1932 at the UK's Royal Institute of International Affairs is a good illustration. He said: "The tasks which the Poles had taken upon themselves was to constitute out of the various races within their territories a united State which, though composed of several nationalities, would be imbued with Western ideals of civilization and would form a bulwark against the westward trend of Bolshevik principles. This task could only be carried through if the Ukrainians were welded into the commonwealth as loyal workers to a common end" (Napier 1932: 408-409). 
identity within an established mnemonic community and in order to reinforce that sense of community, states and political leaders may for political purposes further emphasise specific elements of that collective past while downplaying or simply ignoring other aspects. This is clearly what happened also in this case.

While the official Polish view on the past cultivated the image of the Ukrainians as enemies, Ukrainian minority communities tried to benefit from Poland's formally proclaimed friendship with all the nations of the Soviet Union in order to demand the freedom to develop Ukrainian culture, organize education in the Ukrainian language, conduct religious services, and return to the eastern regions of Poland (Czech 1993: 269). Between 1958 and 1968, a part of the earlier replaced people did indeed return to southeastern Poland. Moreover, a Ukrainian cultural organization was allowed to be established, and a number of Ukrainian magazines and schools were founded. Under party leaders Gomułka and Gierek, however, the policy again became much more restrictive and opportunities for organizing the Ukrainian community in Poland diminished.

Interestingly, towards the end of the 1970s and the beginning of the 1980s Ukrainian activism found support from the growing opposition movement in Poland - especially from independent catholic journals such as Tygodnik Powszechny, Znak and Więź - and from Polish Diaspora publications in the West, not in the least the Paris-based journal Kultura. ${ }^{6}$ The intellectuals associated with Kultura promoted the idea of friendship with an (increasingly) independent (and later also - as they hoped - a more democratic) Ukraine as an ideal way of protecting Poland from the Russian sphere of influence. In order to win such independence in the long term, they argued, short-term Polish claims for revision of the border and the annexation of Ukrainian territory should be abandoned, and instead a process of reconciliation would need to be started.

During the 1980s, Ukrainian activism remained at the margins of the opposition movement mainly because of the rigid assimilation policy that marked this period, but also because the events surrounding Solidarność absorbed almost all of the opposition's energy. Yet, the fact that independent intellectuals and dissident thinkers had paid so much attention to the case of the Ukrainian minority in the early 1980s gave Ukrainian minority activists an enormous advantage when it came to publicizing their cause at the time of the regime change at the end of the 1980s. In the run-up to the round-table negotiations ending communist party-rule in Poland, a number of minority activists among them three Ukrainian activists (Michał Łesiów, Włodzimierz Mokry, and Stefan Kozak) - directed an appeal to Lech Wałęsa demanding that a more generous approach to national minorities be discussed at the round-table talks. The Committee for Cooperation with the National Minorities (Komisja Wspótpracy z Mniejszościami Narodowymi) that was subsequently established within Solidarność, brought intellectuals such as Jacek Kuron and Bohdan Skaradziński together with minority representatives such as the Ukrianian activist Włodzimierz Mokry. Soon thereafter

6 In 1984, Bohdan Skaradziński (using the pseudonym Kazimierz Podlaski) published his influential book Białorusini, Litwini, Ukraincy. Nasi wrogowie - czy bracia? (Belarussians, Lithuanians, Ukrainians: Our enemies or brothers?), which soon became a bestseller. 
Mokry was given a favourable place on the list of Solidarność at the first parliamentary elections. From 1989 to 1991, he was the first Ukrainian minority activist to have a seat in the Polish lower house (Sejm). ${ }^{7}$ Thanks to the work of mainly Kuron and Mokry, a special committee dealing with national minorities was established in the Sejm, and work on new legislative initiatives was started.

Within this committee minority activists initiated discussions regarding such matters as minority language education, minority representation in parliament, protection of cultural heritage and religion; but when it came to the "Ukrainian issue" priority was given to the question of how, after so many years, the injustices resulting from Operation Vistula could be redressed. In other words, the usual minority demands, i.e. demands related to the protection of culture and language and to measure leading to preferential access to political resources through, for example, guaranteed representation, turned out not to be at the heart of Ukrainian activism. These activists rather sought to initiate a debate about the past, because they feared that if the complex history of forced resettlement would not be taken into account in the formation of current minority policy, Ukrainians would not even be able to benefit from any minority legislation. In February 1989, the Ukrainian Socio-cultural Society (Ukrainskie Towarzystwo Spoleczno-Kulturalne) published a report in which it argued that "because of the significant spread of the Ukrainian national minority there is not a single electoral district where there is even the slightest possibility of getting elected representatives, whatever the number of votes may be" (UTSK 1993: 86). Therefore, the organization argued, special method of representation needed to be applied to ensure the presence of Ukrainians in local and national governmental bodies.

In 1990, the Polish upper chamber (Senat) did indeed condemn Operation Vistula, a move which was first welcomed by Ukrainian activists but later also criticized because of the conspicuous lack of concrete proposals for compensatory measures (Czech 1993: 275). The more important condemnation from the Sejm, however, did not follow. And it took more than a decade before the Polish president would express his regret over this historical episode. On the occasion of the 55th anniversary of the events he called Operation Vistula "a symbol of the abominable deeds perpetrated by the Communist authorities against Polish citizens of Ukrainian origin" (quoted in the editorial of The Ukrainian Weekly, May 12, 2002). What is important here is that this condemnation was expressed in a period during which Polish elites stepped up their efforts to establish good relations with Ukraine.

In other words, during the 1990s, the official interpretation of the "Ukrainian question" in Poland shifted. While it was initially framed mainly as a domestic issue related to minority protection it gradually became more important as an element of international politics related to Poland's economic and geopolitical interests. From 1994 onwards, after the election of Kuchma as the president of Ukraine, Poland and Ukraine engaged

7 In elections in 1993 and 1997, other candidates representing the Ukrainian minority were elected as MPs from lists of the liberal Freedom Union (UW) and the Alliance of the Democratic Left (SLD) (Polish Government 2002: 43). 
in bilateral agreements in which declarations regarding the protection of minority rights played only a marginal role.

In contrast to the political elites, Polish media and public opinion throughout the period from 1994 to 2004 continued to see the Ukrainian minority mainly in the context of the domestic animosity of the past. The dominant view of this minority not only remained coloured by stories about Polish-Ukrainian antagonisms during and after the Second World War; the image of the Ukrainians in Poland was also increasingly affected by Polish popular fear for illegal immigration and crime from the East. Polish sociologists have pointed out that the general Polish perception of immigrant workers from Ukraine has been complex. Although in practice Ukrainians have often been regarded as good workers, they are also often associated with illegal trade and black economy (Konieczna 2003).

A striking aspect of the situation of the Ukrainian minority in Poland is that there is a large discrepancy between the dominant negative images of Ukraine and the Ukrainian minority in Polish society and the positive way in which important members of the Polish political elite and the civil society have acted towards Ukraine. Given this state of affairs, Ukrainian minority activists in Poland have not had an easy time communicating their concerns and demands to the state and to the larger public. Did the most recent international developments, especially with regard to the enlargement of the EU, offer a point of support for such Ukrainian activism?

\section{Domestic minority activism in an EU context: exploring the "Ukrainian question" in Polish legislative and policy-making debates}

There are various ways in which one might gain a clearer idea of the way in which Ukrainian minority activists in Poland have perceived the process of European integration and whether they were able to utilize developments on the European level to buttress their demands towards the Polish government. One way to find out, for example, would be to survey Ukrainian minority organizations, ask activists to talk about the daily practice of ethnic mobilization, and infer from these accounts the level of importance activists attach to the changing European context.

Although interviewing minority activists is planned as a part of my overall research project, for this paper I have chosen to focus on the political opportunity structure of domestic mobilization, i.e. the official institutional environment in which minority activists in Poland had to act in the period between 2001 and 2005. When minority activists seek to make their claims heard at the national level they have to do so within an official institutional context consisting of a number of relatively stable elements in the political system, such as the parliament, the ministries, the various government administration units, the extant governmental bodies etc. It is therefore worthwhile to analyze the reports coming from these institutions and explore the context in which these reports mention Ukraine and the Ukrainians. Indirectly, these reports may give an idea of how successful Ukrainian minority activists have been in attracting attention 
to their cause at the highest political level, and to what extent they have relied on the ongoing debate on EU enlargement in order to trigger attention for their case.

With this task in mind, I perused (1) the documents produced by the bodies of central government responsible for minority affairs, (2) the transcripts of the debates in the Sejm commission on ethnic and national minorities during the drafting of the Polish minority law (adopted in December 2004), and (3) the transcripts of the Sejm commission dealing with EU matters.

With regard to the government bodies involved in minority policy a number institutional developments should first be clarified. The latter half of the 1990s saw the establishment of an Interdepartmental Group for National Minority Issues (1997) within the government administration (Międzyresortowy zespół do spraw mniejszości narodowych, hereafter "Interdepartmental Group") and a Division of National Minorities (Wydzial mniejszości narodowych) at the Ministry of Interior and Administration (2000). The former commission gathered the representatives of various governmental departments, but they did not include minority representatives (Vermeersch 2004). The latter was a ministerial body aimed at raising the government's activities in the area. The law on national and ethnic minorities and regional language officially published in January 2005 stipulates the establishment of a Joint Commission of the Government and the National and Ethnic Minorities (Komisja Wspótna Rzadu i Mniejszości Narodowych $i$ Etnicznych) which will function as an advisory body to the government council and will include minority representatives (art. 23 and 24 of Law 141 Ustawa o mniejszościach narodowych $i$ etnicznych oraz o języku regionalnym, Dziennik Ustaw nr. 17).

The reports of the Interdepartmental Group show that the Ukrainian minority was discussed mainly in the context of the following issues: the demand for financing a Ukrainian cultural centre, minority education, access to public media, the restitution of property that once belonged to Ukrainian organisations, and the setting up of a monument in the labour camp site in Jaworzno (a former Nazi concentration camp that from 1947 to 1949 was used by the Polish authorities as a detention camp for Ukrainians suspected of co-operation with the UPA). ${ }^{8}$ Discussions also arose about whether the Ukrainian demands differed from those made by the Lemko community.

During the 9th and the 10th session of Interdepartmental Group (April and June 2000), the importance of European developments was highlighted, but the focus was clearly on the issue of how government administration should help Poland comply with European norms and standards (mainly the Council of Europe's Framework Convention on the Protection of National Minorities), and not on the political consequences of EU membership for Poland's relations with its immediate Eastern neighbours. The EU was

\footnotetext{
8 In 2002, Jacek Kuroń complained that after years of demanding compensations for the people who had been imprisoned in the camp at Jaworzno during Operation Vistula, the Association of Ukrainians in Poland had not managed to persuade policymakers to proceed with such a measure. Kuron did not mention the relationship between Poland and Ukraine as contextual factor that should be taken into account (Kuron 2002).
} 
also a topic of discussion in the 16th session (May 2001), when the participants in the meeting noted that Poland was one of the few candidate countries that had not made any use yet of EU funding for minority programmes. Blame was placed on the minority activists themselves who were claimed not to be interested in these European programmes or missed the expertise to submit successful proposals. In 2002, the EU accession process was mentioned as an important context stimulating the government to step up efforts to prevent discrimination. The Interdepartmental Group discussed, for example, the need to comply with the legal requirements set forth by the EU's Directive 2000/43/EC of 29 June 2000 implementing the principle of equal treatment between persons irrespective of racial or ethnic origin. In 2003, European integration was discussed a number of times by the Interdepartmental Group, but no direct links were made to the position of the Ukrainian minority. Emphasis was again on the consequences of complying with European legal standards such as the European Charter for Regional and Minority Languages. As far as concrete policy development was concerned, the Interdepartmental Group focused mainly on the issue of the Roma.

One important conclusion that can be drawn from the reports of the meetings of the Interdepartmental Group is that Ukrainian minority activists had apparently not utilized - or at least had not been able to utilize successfully - references to the 'strategic partnership' (Wolczuk and Wolczuk 2002) of Poland and Ukraine in order to turn the issue of the Ukrainians in Poland into a matter of governmental concern at the forefront of minority policy.

This conclusion is supported by evidence from the Sejm commission on ethnic and national minorities (Komisja Mniejszości Narodowych $i$ Etnicznych). The main focus of debate in this commission was the draft minority law, initially tabled in 1998. This draft act not only contained provisions forbidding discrimination and assimilation. It also made specific forms of affirmative action possible; mandated the establishment of a commission that would become responsible for the implementation of government policies towards minorities; and it increased the possibilities for utilising minority languages in the public sphere in areas inhabited by sizeable minority groups. At the end of 2004, it finally led to the adoption of the law on national and ethnic minorities and regional language.

In this commission, minority representatives were frequently heard. At these occasions, the Ukrainian minority was represented by the president of the Association of Ukrainians in Poland (Związek Ukrainców $w$ Polsce), Miron Kertyczak. From the comments made by Kertyczak in the commission, one can conclude that Ukrainian affairs were seen very much in the context of the demands made by minorities in general. For example, at various times Keryczak highlighted the importance of the minority law and expressed his hope that the work on that law would be continued and lead to the adoption of the law. He also emphasized the importance of a sustained financial state support for the publication of minority magazines and journals. When it came to topics more related to the specificities of Ukrainian-Polish relations, the discussion revolved around the legacy of Operation Vistula. Ukrainian activists demanded not only a final official condemnation of Operation Vistula but also wanted to 
see an initiative from the policymakers to regulate material reparations and support commemoration (e.g. through establishing monuments).

Of course, the debates in this parliamentary commission do not provide us with an exhaustive overview of the political action of the Ukrainian minority in Poland. They do, however, give us an idea of what Ukrainian minority leaders have regarded as crucial issues, i.e. what issues they have hoped to bring into the debate, or what issues they have hoped would stand a reasonable chance of being of some sort of influence in the parliamentary debate on the subject. From this point of view it is remarkable that in the interventions made by the president of the Association of Ukrainians in Poland no link was made between the situation of the Ukrainian minority in Poland and the diplomatic efforts of the government to improve diplomatic relations with Ukraine.

In this context, the transcripts of the discussions held in the parliamentary Commission for EU Affairs (Komisja do Spraw Unii Europejskiej, SUE) are also an interesting source of information. Although Ukraine was an important topic of discussion in this commission, a number of other important topics were not brought up by the participants. For example, one will find no information on the opinion of the commission members on the Ukrainian minority in Poland or on the way Ukraine should deal with its Polish minorities. Furthermore, there were no references to the historical context of Polish-Ukrainian relations. The emphasis in this commission was clearly on Poland's current short-term goal: bringing Ukraine as close as possible to EU accession. This issue was seen as completely separated from the debate on national minority protection. Andrzej Załucki, vice-secretary of state at the Ministry of Foreign Affairs, summarized the general tenet of the debates in the commission very aptly: "There is complete consensus and understanding not only with regard to Ukrainian aspirations, but also with regard to the need to find a place for Ukraine in the European family" (SUE nr. 55, Biuletyn nr. 4190/IV, February 19, 2005). The need to find a place for Ukrainians in Poland was apparently not seen as in any way related to this issue. The vice-secretary of state at the Ministry of Foreign Affairs, Jan Truszczyński, made clear that in the context of improving bilateral relations between Poland and Ukraine the larger European environment would be of crucial importance:

Our task and goal remains to date: developing and realizing the European Neighbourhood Policy and persuading Ukraine that it is important to become involved in realizing this policy, to add another floor to the building that Ukraine has been able to put up so far in cooperation with the EU. (SUE nr. 8, Builetyn nr. 3471/IV, July 23, 2004)

The conclusion that there is consensus among the main Polish political actors about the need to support Ukrainian membership of the EU but that there is no need felt to create a link with domestic discussions about historical antagonisms between Poles and Ukrainians, is much in keeping with conclusions from other research projects. One example is the analysis made by Copsey and Szczerbiak (2005) of the political programmes that Polish political parties presented to their potential voters during the election campaign for the European parliamentary elections in June 2004. These 
authors found out that there was a broad consensus among political parties about the way in which policy towards Ukraine should be viewed. Virtually all of the parties encouraged the development of a strong, independent and pro-Western Ukraine as an important element in preserving Polish independence from Russia. Within this consensus, only some parties - most notably the radical conservative League of Polish Families (LPR) - formulated a policy on Ukraine that put emphasis on the position of the Polish minority and the Catholic Church in Ukraine, not on the process of democratization of Ukraine (Copsey and Szczerbiak 2005: 17). Yet, it is to some extent remarkable, that none of the parties, however extreme, favoured a policy of border revision or annexation of border territories. And it is perhaps equally remarkable that none of the parties, however pro-European and however in favour of minority rights protection (such as, for example, the Freedom Union, UW), used this international context to bring the situation of the Ukrainians in Poland into the centre of attention.

\section{EU enlargement: are there any links to the process of reconciliation?}

Has EU enlargement, then, been an important part of the international political opportunity structure of Ukrainian activism in Poland? In general, the findings of the paper point to the need to problematize the concept of "transnational political opportunity structure." Just as movement identities (including ethnicity) are constructed by a range of actors in the course of collective action (rather than that they are a stable source of collective action), one can argue that transnational political opportunities are constructed during the process of mobilization. Identifying these political opportunities is not at all an easy affair (Meyer 2004). In order to know whether institutional and political developments on the transnational level can function as opportunities, one must carefully examine the ways in which actors perceive, interpret and portray these developments. In the case of the Ukrainian minority in Poland, EU enlargement appears to offer a crucial opportunity to activists for bringing their case to the attention of domestic political actors. In practice, however, Ukrainian activists have not been able to seize this opportunity and their demands remain to date largely situated in a domestic context.

By way of concluding this paper, it might be in order to think of plausible reasons for the fact that the issue of support for the Ukrainian minority has been - institutionally and in terms of official discourse - completely separated from the issue of Polish support for Ukrainian membership of the EU.

One reason may have to do with the fact that dominant political actors in Poland do not associate Polish support for the European aspirations of Ukraine with relations between Poles and Ukrainians, but rather with Polish geopolitical interests.

A second reason may be related to the content of the demands made by the Ukrainian minority organisations. These demands are not about international relations. They have mostly concerned the development of local culture, reparations, monuments and commemoration and the preservation of culture and language through publications and 
education. Demands are not focused on the preservation of cross-border ties, the possibility to receive support from their homeland or the facilitation of travel and migration to and from Ukraine. This is caused in part by the fact that the Ukrainian government itself is not particularly active in supporting the Ukrainian minority in Poland. If neither the Polish nor the Ukrainian government make a connection between their foreign policy regarding the EU and the treatment of the Ukrainian minority in Poland, it is difficult for Ukrainian organizations to seize the international context as an opportunity for making their claims heard.

\section{Acknowledgements}

I would like to thank Dariusz Niedźwiedzki, Jacek Nowak, Grzegorz Babiński, Irina Zbrozhek, and Sebastian Zaleski for assistance. 


\section{REFERENCES}

Benford, Robert D., and David A. Snow (2000), 'Framing Processes and Social Movements: An Overview and Assessment', Annual Review of Sociology 26: 611-39.

Brubaker, Rogers (1996), Nationalism Reframed: Nationhood and the National Question in the New Europe. Cambridge: Cambridge University Press.

Brubaker, Rogers (2004), Ethnicity Without Groups. Cambridge, London: Harvard University Press.

Copsey, Nathaniel and Aleks Szczerbiak (2005), "The future of Polish-Ukrainian elections: evidence from the June 2004 European Parliament election campaign in Poland' Sussex European Institute Working Paper, 48.

Czech, Mirosław (1993), 'Kwestia ukraińska w III Rzeczypospolitej', in: Związek Ukraińców w Polsce (ed.), Ukraincy w Polsce 1989-1993: Kalendarium, dokumenty, informacje, Warszawa, 268-289.

Główny Urząd Statistyczny (2003), Narodowy spis powszechny ludności i mieszkań. Raport z wyników, Warszawa.

Ferrero-Waldner, Benita (2005), 'Накануне важного шага', Зеркало Недели, 534 (English version available at http://www.delukr.cec.eu.int/site/page34090.html)

Fidev, Lesya (2004), 'Pole-axed', Transitions Online, 30 January 2004.

Górny, Agata and Ewa Kępińska (2004), 'Mixed marriages in migration from the Ukraine to Poland', Journal of Ethnic and Migration Studies 30(2), 353-372.

Guidry, John A., Kennedy, Michael D., and Zald, Mayer N. (eds.) (2000), Globalizations and Social Movements. Culture, Power, and the Transnational Public Sphere. Ann Arbor: The University of Michigan Press.

Hann, Chris (1998), 'Postsocialist nationalism: rediscovering the past in southeast Poland', Slavic Review 57(4), 840-863.

Irwin-Zarecka, Iwona (1994), Frames of Remembrance: The Dynamics of Collective Memory, New Brunswick, N.J.: Transaction.

Keck M. and K. Sikkink (1998), Activists beyond borders. Transnational Advocacy Networks in International Politics. Ithaca, London: Cornell University Press.

Kelley, Judith (2004), Ethnic Politics in Europe. The Power of Norms and Incentives. Princeton, Oxford: Princeton University Press. 
Kertzer, David I., and Dominique Arel (eds.) (2002) Census and Identity. The Politics of Race, Ethnicity, and Language in National Censuses. Cambridge: Cambridge University Press.

Kriesi, Hanspeter, Ruud Koopmans, Jan Willem Duyvendak, and Marco G. Giugni (eds.) (1995), New Social Movements in Western Europe: A Comparative Analysis. London: UCL Press.

Kuroń Jacek (2002), 'Rozumiem protest Ukraińców' (noted by Iza Chruślińska and Wojciech Duszenko), Gazeta Wyborcza, 23 May 2002, p. 14.

Konieczna, Joanna (2003), 'Polacy-Ukraińcy, Polska-Ukraina. Paradoksy stosunków sassiedzkich', Working paper published by the Batory Foundation, Warsaw, http://www.batory.org.pl/doc/paradoksy.pdf

McAdam, Doug (1982), Political Process and the Development of Black Insurgency, 19301970. Chicago: University of Chicago Press.

McAdam, Doug, John D. McCarthy, and Mayer N. Zald, (eds.) (1996), Comparative Perspectives on Social Movements: Political Opportunities, Mobilizing Structures and Cultural Framings. Cambridge: Cambridge University Press.

Meyer, David. S. (2004), 'Protest and Political Opportunities' Annual Review of Sociology 2004(30): 125-145.

Miszczuk, Andrzej, 'Pogranicze polsko-ukraińskie a polityka zagraniczna III RP', in: Ryszard Stemplowksi \& Adriana Żelazo (eds), Polskie pogranicza a polityka zagraniczna u progu XXI wieku, Polski Instytut Spraw Międzynarodowych, Warszawa, 263-280.

Napier, Walter (1932), 'The Ukrainians in Poland: An historical background', International Affairs 11(3), 391-421.

O'Dowd, Liam and Thomas M. Wilson (1996), 'Frontiers of sovereignty in the new Europe', in: ed. Liam O'Dowd and Thomas M. Wilson, Borders, Nations and States, Aldershot: Avebury.

Polish Government (2002), 'Report to the secretary general of the Council of Europe on the realisation by the Republic of Poland of the provisions of the Framework Convention of the Council of Europe for the Protection of National Minorities'.

Prodi, Romano (2002), 'A Wider Europe - A Proximity Policy as the key to stability' speech delivered at the Sixth ECSA-World Conference "Peace, Security And Stability International Dialogue and the Role of the EU", Brussels, 5-6 December 2002. 
Snyder, Timothy (1999), "To Resolve the Ukrainian Problem Once and for All": The Ethnic Cleansing of Ukrainians in Poland, 1943-1947', Journal of Cold War Studies $1(2), 86-120$.

Risse, Thomas, and Kathryn Sikkink (1999), "The Socialization of International Human Rights Norms into Domestic Practices: Introduction." In The Power of Human Rights: International Norms and Domestic Change, ed. T. Risse, S.C. Ropp, and K. Sikkink. Cambridge: Cambridge University Press, 1-38.

UTSK (Ukraińskie Towarzystwo Społeczno-Kulturalne) (1993), '1989 luty 26, Warszawa - Raport Ukraińskiego Towarzystwa Społeczno-Kulturalnego pt. "Ukraińcy w Polsce Ludowej"' in: Związek Ukraińców w Polsce (ed.), Ukraincy w Polsce 1989-1993: Kalendarium, dokumenty, informacje, Warszawa, 86-98.

Vermeersch, Peter (2004), 'Minority policy in Central Europe: exploring the impact of the EU's enlargement strategy', The Global Review of Ethnopolitics 3(2), 3-19.

Vermeersch, Peter (2005), 'EU enlargement and immigration policy in Poland and Slovakia', Communist and Post-communist Studies 38(1), 71-88.

Wilczak, Jagienka (2004), 'Wizy za dewizy', Polityka 25(2457), 30-33.

Wolczuk, Kataryna and Roman Wolczuk (2002), Poland and Ukraine. A Strategic Partnership in a Changing Europe? London: Royal Institute of International Affairs.

Zerubavel, Eviatar (1999), Social Mindscapes: An Invitation to Cognitive Sociology. Cambridge, London: Harvard University Press. 